\title{
Re-thinking civil disobedience
}

\section{Theresa Züger}

Alexander von Humboldt Institute for Internet and Society, Berlin, Germany,

theresa.zueger@hiig.de

Published on 11 Nov 2013 | DOI: 10.14763/2013.4.216

\begin{abstract}
This article points out a struggle of today's societies with the traditional concepts of civil disobedience and stresses the need for reevaluation of the concept of civil disobedience for policy making and public discourse. Starting with a minimal definition of civil disobedience, the article introduces Hannah Arendt's approach for a legitimisation of civil disobedience and discusses her ideas for digital actions, which are increasingly framed as digital forms of civil disobedience. Addressing WikiLeaks as an example of digital civil disobedience, the author problematises the internal secrecy of WikiLeaks and the focus on Julian Assange as a single decision-maker. Both aspects challenge Arendt's understanding of legitimate civil disobedience. Even though traditional criteria of civil disobedience need to be revisited in the digital age, organisations or disobedience actors might themselves in their actions be well-advised to comply with the principles they fight for.
\end{abstract}

Keywords: Activism, Civil disobedience, Online civil disobedience, Hacktivism, Wikileaks, Whistleblower, Edward Snowden, Hannah Arendt

\section{Article information}

Received: 23 Sep 2013 Reviewed: 05 Nov 2013 Published: 11 Nov 2013

Licence: Creative Commons Attribution 3.0 Germany

Competing interests: The author has declared that no competing interests exist that have influenced the text.

URL: http://policyreview.info/articles/analysis/re-thinking-civil-disobedience

Citation: Züger, T. (2013). Re-thinking civil disobedience. Internet Policy Review, 2(4).

https://doi.org/10.14763/2013.4.216

Civil disobedience is a familiar and well established phenomenon in Western societies. Currently, this concept of political action is challenged by new practices evolving on and around the internet. This brings up serious questions - not only in theory, but urges societies to take a stand and to negotiate how much dissent is necessary in a democracy. This article argues that the benefits for society implied by the application of Arendt's thought and beyond, would not only help question traditional theory of civil disobedience, but also reflect upon new adaptations of the concept. This paper will therefore focus on the question of whether different forms of digital civil disobedience are legitimate. So as to get to grips with the complexity of this concept, we will first define civil disobedience in minimal terms. 


\section{NEW PLAYGROUND FOR OLD QUESTIONS}

Besides an extraordinary amount of previously confidential information, Edward Snowden, Chelsea (formerly Bradley) Manning and other whistleblowers provided the general public with a more general insight: societies of our time quarrel with the concept of civil disobedience. Albeit civil disobedience is a dedicated term, it is today being revisited - its forms are being adapted to new technical possibilities and to the environment of the information age. Scholars Yochai Benkler (Benkler, 2011) and Manuel Castells (Castells, 2011) rightly emphasise that internet collectives and social media platforms, such as WikiLeaks, assemble and organise arrangements of power. WikiLeaks not only modifies the processes of investigative journalism and shifts theoretical borders of public spaces towards a global audience (Cohen \& Castillo, 2011), it also challenges the concept of civil disobedience at all levels: political philosophy, policy and in the mind of the public.

Hannah Arendt was already reflecting on civil disobedience in 1970, studying how it could become a lively and intrinsic part of pluralistic democracies. The reality is that the disobedient are treated as plain criminals, even more if the disobedience focusses on the internet. Admittedly, civil disobedience is a social phenomena, which is not easy to handle for policy makers. To my knowledge, there is no law in any jurisdiction that directly addresses civil disobedience and there is no lawful right of citizens to practice it. The opposite is the case. Robin Celikates, a scholar of political philosophy, describes civil disobedience in a minimal definition as an

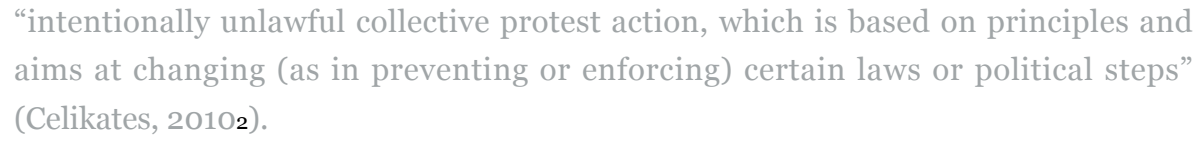
aims at changing (as in preventing or enforcing) certain laws or political steps" (Celikates, 20102).

Furthermore, civil disobedience pursues a communicative intention, meaning that the motivating principles should be communicated. Even though there is no right of civil disobedience, it is often argued that there is a moral right (Lefkowitz, 2007) or even a duty to oppose policies and court rulings and their enforcement under certain circumstances. Usually, the disobedient relies on the belief in a so-called prima-facie-illegality (Dreier, 1983, p. 56), meaning that something is illegal at the time of the protest but becomes lawful later on, possibly as a consequence of the protest.

Snowden and Manning could be forerunners of a larger movement. How policy makers will deal with these new forms of dissent will have consequences for civil rights and the capacities of modern democracies to learn. Rationally reflecting upon their actions in a political context, is no task for policy makers alone. It is the duty of society as a whole, as civil disobedience not only addresses politicians in a particular public debate, but first of all, civil society.

The legitimacy of civil disobedience is a complex question, often falling short in public discourse. The following introduction of Arendt's concept of civil disobedience, may provide a new perspective on the question of legitimacy of civil disobedience, that hopefully can serve as an entry point for further discussion. 


\section{POLITICS IS WHERE THE PEOPLE ARE}

Civil disobedience is a concept of political participation with a long tradition in direct action but also in political philosophy. Arendt describes civil disobedience developing, when a meaningful amount of citizens, but not necessarily a majority, come to the conclusion that common ways of opposition to their government don't exist or get ignored (Arendt, 2012, p. 299). She addresses cases in which a government pursues actions or decisions that do not conform to the law or the constitution (ibid., p. 299). I argue that even though there is overarching criteria for the legitimacy of civil disobedience, it also depends on the political situation in which a society is, and the character of the deeds or tactics performed, to decide whether an action is appropriate and legitimate. There is no one-size-fits-all judgement.

For Arendt, the crucial criterion for these actions is first of all the criteria of publicity. While criminals avoid the public eye, the civil disobedient longs for its attention (ibid., p.30o). As well, collectiveness and the orientation on the common well being of a society are necessary criteria for the legitimacy of civil disobedience. In Arendt's understanding, they are truly political if they serve a horizontal alliance between all citizens, which respects plurality and diverse opinions. For her, it makes a significant difference if individuals publicly state their political opinions or simply represent their personal interests (ibid., p. 308).

The principles that civil disobedience relies on - in Arendt's view - cannot solemnly derive from the personal conscience, as proposed by US-American author and philosophical thinker 3 Henry David Thoreau. The conscience decides what a person is willing to live with, but this decision ultimately remains a private one. The individual conscience therefore would be too variable, demanding nothing in principle - which, for Arendt, makes it in its very nature unpolitical (Arendt, 2012, p. 289). In Arendt's view, Thoreau's action cannot be considered civil disobedience, because in her definition civil disobedience cannot be practiced by a single person and needs to be pursued in public. Only a collective and the public have the power to transform an individual's conscious view into a political opinion.

Arendt's concept of civil disobedience also has significant differences with respect to the well known one of John Rawls, a liberal US-American philosopher. They differ in certain questions regarding the legitimacy of civil disobedience. They disagree on whether disobedience can only be legitimate when the disobedient takes on the penalty or, whether he needs to accept the political system in general (ibid, p. 285, 301; Rawls p. 403). This discussion is outside the scope of this paper, but it goes to show that civil disobedience is not a self explanatory term.

Most important to distill from Arendt's political theory is, that a democracy should offer room for dynamic and conflicts, so as to promote plurality. The truly political moment of human life for Arendt is the possibility to create new and unforeseeable beginnings. Even though the idea to integrate disobedience into a system seems like a paradox from a legal perspective, she thinks about solutions on how to institutionalise civil disobedience as a balance to the failures of legal examination, for example via "pressure groups" (Arendt, 2012, 319f). Arendt points out that civil disobedience is not a disease of modern democracies, but could well be a cure. 


\section{DIGITALISATION OF CIVIL DISOBEDIENCE AND THE LAW}

Increasingly, the term civil disobedience is brought into play in cases of online activism. In the late 1990s, pioneers such as the Electronic Disturbance Theater or the Electrohippies practiced politically motivated DDoS attacks (Jordan \& Taylor, 2004, p. 73). They self-coined their actions 'electronic civil disobedience'. Even though digital forms of civil disobedience are historically associated with the practice of DDoS actions, there are many more possible practices. The most recognised global movements today in this field are WikiLeaks and the Anonymous movement. Even though the public discourse - at least on the internet - focuses on several practices, civil disobedience is not defined by a certain set of actions.

Recently, prominent tactics have been discussed as digital forms of civil disobedience. Using the technology and infrastructure of the internet as a tool (and sometimes taking place online), they are, among other:

- DDoS actions (in very different technical forms)

- Whistleblowing

- Infringements of copyright law

- Modification of data use

The idea that electronic or digital disobedience is just a 'virtual sit-in' 4 that observers of the discourse could assume, is tempting - because this analogy is rather simple to understand for the less internet-savvy citizen - but has its weaknesses. It challenges Arendt's concept of civil disobedience, for which publicness is crucial. In online activism people are not necessarily present with their physical body, they are also not as visible - even though absolute anonymity is in fact a myth. The participants of digital civil disobedience might be trackable by executive powers but still, they remain anonymous in front of other citizens during their action.

A big issue, which needs much deeper discussion is the question of publicness of these actions. If something is announced via e-mail or in a video on Youtube, does this mean it is public in a political sense? The user who requests a website and cannot reach it, will not necessarily even realise that there might be a politically-motivated reason for it. The internet's infrastructure modified the ways in which information becomes public in new fragmented digital public spheres (Münker, 2009), which diffuses the public attention. For Arendt, a shared public space is a crucial component for any political action. But shouldn't protest be apprehensive about the audience it is addressing and if so, how could this be realised? The internet provides its own infrastructure and therefore its own practices. Practices of civil disobedience adapt to circumstances and are defined by a complex arrangement of criteria (Celikates, forthcoming) the same is true for digital forms, albeit in new ways (Manion \& Goddrum, 2000, p. 15). This makes them per se no more or less legitimate, but requires a new evaluation and a closer look.

What may seem to be merely a matter of wording about online activism, can also be framed as a struggle about the moral legitimacy of civil disobedience in certain digital forms 5 . Stakeholders in this discourse seem not to support a coherent judgement - they vary between 'hero', 'martyrdom' and 'terrorism' (Furnell \& Warren, 1999) - remarkably there is very little in between. The concept of civil disobedience and how it is enacted on the internet offers a wide range of interpretations.

In Europe, some tribunals struggled to judge civil disobedience taking into account dynamics of 
the internet6. In 2005, the EU Council raised new minimal standards for computer and internet crime-related court rulings within European member states. The implementation of these standards in the German criminal law for example, namely mentions DDoS attacks under article $303 \mathrm{~b}$ as a case of computer sabotage. From a philosophical point of view, it is remarkable that the motivation of the party engaging in online criminal activity is legally not taken into account. On the other hand, the varying definitions and the underdeveloped public discourse about digital forms of civil disobedience does not provide policy makers with any orientation. This struggle involves questions about the understanding of democracy, including civil rights and duties. Answers to these questions have direct consequences on jurisdiction and internet policy, which in turn are constitutive of the future of digital protest and civil rights online and offline.

\section{THINKING WITH ARENDT ABOUT WIKILEAKS}

As stated earlier, the argument we are making is not meant to establish whether certain forms of civil disobedience are normatively good or bad. Rather, we are trying to establish the common criteria to WikiLeaks and some of Arendt's ideas. Only then will we be able to discuss grey areas.

Arendt's considerations are possibly more relevant than ever. Since 2006, WikiLeaks, a webbased whistleblower model, is one of the initiatives that effectively and profoundly confronts the public with the question of the role disobedience should play in society. Do we live in a society that appreciates and protects whistleblowers - also by making appropriate laws and policies or do we see them as criminals that endanger stability?

First, in what way could WikiLeaks possibly be considered - using the minimal definition indicated above - a form of civil disobedience? WikiLeaks 7 , as a media organisation functions as a transmitter for secretive information with assumed public interest, which understands itself as a group of journalists and publishers (Cohen \& Castillo, 2011). Another actor in the WikiLeaks network is the whistleblower, who holds secretive information and decides to provide it to the WikiLeaks collective by uploading it anonymously via an online submission form (Fuchs, 2011)8. A globally spread public as receiver of this information, could be seen as yet another actor in this context. "WikiLeaks is engaging in political struggles, is an explicitly politically motivated project, and wants to make information public that has to do with the abuse of power" (Fuchs, 2011). Even though this might be true in general, each publication must be seen in its own context, to fully analyse its moral implications. In order to break this line of argument down to one example, this article focuses on the 'Collateral Murder' video, that was published in April 2010, showing the killing of civilians by the US air force.

In order to cross-check our understanding, we need to go back to the minimal definition of civil disobedience: Firstly, the illegality criteria is not easy to answer. WikiLeaks, as a platform for investigative journalism, is not in itself illegal. So far, there has been no public prosecution against the practice of the WikiLeaks founder and WikiLeaks co-workers. According to the first amendment in the United States of America, such a group is generally allowed to publish secret information if it is of public interest, as in the case of the Pentagon Papers. The unlawful act of breaking a non-disclosure clause usually behooves a single individual, such as Chelsea Manning. Nevertheless, WikiLeaks, as an organisation, is unofficially accused of promoting this unlawful act.

Secondly, the organisation necessary to publish the 'Collateral Murder' video is rooted in collective action, made up of (and dependent on) the whistleblower Manning, the WikiLeaks 
collective and the WikiLeaks platform. Besides this, WikiLeaks' work depends on donations by supporters. In the months from November 2010 to January 2011, the donations added up to a peak of 800,00o Euro, which could be interpreted as an indicator of a meaningful amount of people supporting this initiative.

Concerning the other necessary criteria: WikiLeaks enacts a form of intentional protest and aims to change political decisions and certain laws. The collective itself testifies to act upon principles, which can be perceived publicly, and even depend on principles, which are quite widespread, such as the Universal Declaration of Human Rights. The communicative intent can be found in the practice of publishing via the internet, as well as via established media outlets.

In my understanding, WikiLeaks' act of publishing the 'Collateral Murder' video can be defined as a digital practice of civil disobedience, noting that this definition is based on the attempt of descriptive criteria and even self-descriptions by the collective and, does not yet allow for any conclusion about its legitimacy.

\section{LEGITIMACY OF ONLINE CIVIL DISOBEDIENCE}

In line with the most prominent of Arendt's criteria - performing civil disobedience in public WikiLeaks is definitely seeking public attention and, it claims to support civil interests. Taking a closer look, one has to admit that the criteria of being public, is in this case tricky. WikiLeaks addresses the public with its reports, but due to the nature of the material it works with, WikiLeaks itself is rather opaque when it comes to the way in which it is organised and how the information is processed. Traditional actions of civil disobedience appear to be way more straight-forward and transparent for the public's eye. Do the political circumstances - the lack of transparency of government decisions - that WikiLeaks addresses, justify new handling of this criteria? Arendt stresses that the difference between criminal actions and civil disobedience is that the latter is an "open violation of the law, performed in public" (Arendt, 2012, p. 300)9. This raises the question to what extent the proceedings of civil disobedience must be transparent to the public, when secrecy is a distinctive part of the disobedient act. For Arendt, conspiracy is a completely inapplicable accusation of the civil disobedient. Does this hold true for the WikiLeaks collective, or is a WikiLeaks act like the publishing of the 'Collateral Murder' video in part a form of conspirational civil disobedience? Would Arendt draw the same line in the information society we live in today? Or is this something she could in her time not have thought of and, we should start to think about now?

Another critical issue, which might be problematic, is that only the voice of one single person, in this case Julian Assange's, the founder and chief spokesperson of WikiLeaks, dominates the views and decisions of the supposedly collective action. What Arendt's concept points to is, that civil disobedience is not to be a playground for heroes. In her version, it is not personalities but a cause, that plays the lead part. It might be hard to evaluate this principle in relation to a mediated public, longing for stories and sensations.

In its new digital forms and facing a mediated and fragmented public, civil disobedience confronts societies with several challenges. In my view, there are several 'grey' areas to think about, which cannot all be addressed here. On the level of the civil society, it provokes dispute about what types of civil disobedience are legitimate and which ones draw public support. This demands more knowledge and an assessment of new tactics and practices. The mass media still play a dominant role by selecting, interpreting and presenting cases of civil disobedience. They 
could become a decisive factor in influencing the future and variety of disobedient acts.

In conclusion, where do we stand today in terms of civil disobedience? A number of recent public acts - of which I have provided an example - show, that civil disobedience is a very lively part of our political environment. WikiLeaks' practice can be considered civil disobedience. The debate about the legitimacy of WikiLeaks and other forms of digital civil disobedience has just started and needs further discussion. Existing theories, including Arendt's, encounter their limits and need to be adjusted to an increasingly digital world. On the other hand, movements such as WikiLeaks, nevertheless should comply with reasonable criteria of legitimacy, if they not only wish to stand up against non-transparent governments, but also for, in Arendt's terms, a horizontal alliance between all citizens (Arendt, 2012, p. 308).

The recent international policy reactions to online civil disobedience show that we are not looking at marginal actions or a villain's hoax. The intensity of the pursuit or the prosecution that WikiLeaks and other activists see themselves confronted with, reveals that governments fear the civil disobedient to a disconcerting extent.

\section{FOOTNOTES}

1. Celikates separates the definition from his argument about legitimacy. This definition therefore only answers the question: What is civil disobedience? and not: what is legitimate civil disobedience? I follow the same line of thought, by separating these arguments.

2. Free translation by the author.

3. Thoreau, who is often stated to be the inventor of the term 'civil disobedience', refused to pay his taxes to protest against slavery and the American war against Mexico and defended this idea two years later in his well known essay on "resistance to civil government." His passionate text grounds the duty for civil disobedience in the conscience of the individual (Thoreau, 1993).

4. This analogy was first introduced by the Electronic Disturbance Theater in 1998. The idea is that a DDoS action mirrors a physical sit-in closely, because "a body was required behind each connection to the targeted sites" (Jordan \& Taylor, 2004, p. 73).

5. See, for instance: Manion, Mark \& Goodrum, Abby (2000): Terrorism or Civil Disobedience. Toward a Hacktivist Ethic, ACM SIGCAS Computers and Society, Vol. 30, Issue 2, pp. 14 - 19.

6. For instance in the "Lufthansa case," two German courts, on two levels of jurisdiction, came to different conclusions. The judgment finally made, today would be valid after an amendment to an act (§303 StGB) from 2007. For more detail: Valerius, Brian (2008): Zur Strafbarkeit virtueller Sit-ins im Internet, in: Dimensionen des IT-Rechts, Eric Hilgendorf (Hg), Berlin Logos Verlag, pp. 18-41.

7.: WikiLeaks is a non-profit and non-commercial whistleblowing platform. An organisation which functions through different actors and levels involved. At its core, there is a group of people who receive, select, portion, distribute and publish information on a globally accessible internet website, which is constitutive for this action to take place.

8. WikiLeaks received wide public attention, in great part due to cooperations with mass media institutions, such as The Guardian, The New York Times and Der Spiegel, which, additionally to receiving information by WikiLeaks, analysed and published it. 
9. Translated by the author. 


\section{REFERENCES}

Arendt, H. (2012). In der Gegenwart: Übungen im politischen Denken II. München: Piper. In English: Arendt, H. (1972). Crises of the republic: Lying in politics, civil disobedience on violence, thoughts on politics, and revolution (Vol. 219). Houghton Mifflin Harcourt.

Benkler, Y. (2011). Free irresponsible press: Wikileaks and the battle over the soul of the networked fourth estate, A. Harv. CR-CLL Rev., 46, 311.

Boyd, D. (2013). Whistleblowing is the new civil disobedience. Why edward snowden matters. Retrieved from

http://www.zephoria.org/thoughts/archives/2013/o7/19/edward-snowden-whistleblower.html

Castells, M. (2009). Communication power. Oxford University Press.

Celikates, R. (2010). Ziviler ungehorsam und radikale Demokratie. In T. Bedorf \& K. Röttgers (Eds.), Das politische und die politik. Suhrkamp Berlin.

Celikates, R. (n.d.). Ziviler ungehorsam - zwischen Gewaltfreiheit und Gewalt. In O. FlügelMartinsen \& F. Martinsen (Eds.), Politische Philosophie der Gewalt.

Hart, C., \& Castillo, A. (2011). WIKILEAKS: Journalism and the 21st century madiascape. Global Media Journal, 5(1).

Conway, M. (2003). Hackers as terrorists? Why it doesn't compute. Computer Fraud \& Security, 2003(12), 10-13.

Dreier, R. (1983). Widerstandsrecht und ziviler Ungehorsam im Rechtsstaat. In P. Glotz (Ed.), Ziviler ungehorsam im rechtsstaat (pp. 54-75). Suhrkamp.

Fuchs, Christian: Wikileaks: power 2.0? Surveillance 2.0? Criticism 2.0? Alternative media 2.0? A political-economic analysis, in: global media journal Vol. 5(1), see at http://www.hca.uws.edu.au/gmjau/archive/v5_2011_1/fuchs_RA.html

Furnell, S. M., \& Warren, M. J. (1999). Computer hacking and cyber terrorism: The real threats in the new millennium? Computers \& Security, 18(1), 28-34. Retrieved from Google Scholar.

Isaacs, D. (2013). Heroes of civil disobedience: Gandhi, rosa parks, aaron swartz? Retrieved from

http://www.chicagoreader.com/chicago/did-aaron-swartz-do-right-peter-ludlow/Content?oid= 9015762

Jordan, T., \& Taylor, P. A. (2004). Hacktivism and cyberwars: Rebels with a cause? Psychology Press.

Lefkowitz, D. (2007). On a moral right to civil disobedience*. Ethics, 117(2), 202-233.

Manion, M., \& Goodrum, A. (2000). Terrorism or civil disobedience: Toward a hacktivist ethic. ACM SIGCAS Computers and Society, 30(2), 14-19.

Morozov, E. (2010). In defense of ddos. Denial-of-service attacks: Just another form of civil disobedience. Retrieved from www.slate.com:

http://www.slate.com/articles/technology/technology/2010/12/in_defense_of_ddos.html 
Münker, S. (2012). Emergenz digitaler öffentlichkeiten. Suhrkamp Verlag.

Rawls, J. (1977). Eine Theorie der Gerechtigkeit. Suhrkamp Verlag. English: Rawls, J. (1972). A theory of justice. Oxford, Clarendon Press.

Stone, M. (2012). Martyrdom: Anonymous hacktivist convicted for civil disobedience. Retrieved from

http://www.examiner.com/article/martyrdom-anonymous-hacktivist-convicted-for-civil-disobe dience

Thoreau, H. D. (1993). Civil disobedience, and other essays. New York: Dover Publications. 